\title{
Copper-Promoted Cross-Coupling Reactions for the Synthesis of Aryl(difluoromethyl)phosphonates Using Trimethylsilyl(difluoromethyl)phosphonate
}

\author{
Kazuki Komoda ${ }^{1}\left(\right.$, Rei Iwamoto ${ }^{2}$, Masakazu Kasumi ${ }^{1}$ and Hideki Amii ${ }^{1, *}$ \\ 1 Division of Molecular Science, Graduate School of Science and Technology, 1-5-1, Tenjin-cho, Kiryu, \\ Gunma 376-8515, Japan; t162a004@gunma-u.ac.jp (K.K.); t11801125@gunma-u.ac.jp (M.K.) \\ 2 Department of Chemistry, Graduate School of Science, Kobe University, Nada-ku, Kobe 657-8501, Japan; \\ qq5f25s9n@energy.ocn.ne.jp \\ * Correspondence: amii@gunma-u.ac.jp; Tel/Fax.: +81-277-30-1280
}

Academic Editor: Norio Shibata

Received: 17 November 2018; Accepted: 10 December 2018; Published: 11 December 2018

\begin{abstract}
A convenient and effective route for the synthesis of aryl(difluoromethyl)phosphonates has been developed based on cross-coupling reactions. Upon treatment with a stoichiometric amount (or a catalytic amount in some cases) of $\mathrm{CuI}$ and $\mathrm{CsF}$, aryl iodides reacted smoothly with (silyldifluoromethyl)phosphonates to give the corresponding aryl(difluoromethyl)phosphonates in good yields.
\end{abstract}

Keywords: phosphonates; difluoromethyl; cross-coupling; copper; silicon

\section{Introduction}

Fluorinated organic compounds play important roles in the progress of medicinal, agricultural, and material sciences [1-9]. Difluoromethylene compounds have been important synthetic targets due to the unique properties of the $\mathrm{CF}_{2}$-moiety, which acts as a bioisostere for an ether oxygen atom or a carbonyl group [10-12]. Organic compounds containing difluoromethylphosphonate moieties $\left(-\mathrm{CF}_{2} \mathrm{PO}(\mathrm{OR})_{2}\right)$ are of great interest for application as protein tyrosine phosphatase (PTP) inhibitors [13-17]. Among them, aryl(difluoromethyl)phosphonates $\left(\mathrm{Ar}-\mathrm{CF}_{2} \mathrm{PO}(\mathrm{OR})_{2}\right)$ have received a great deal of attention in the design and development of bioactive agents. Currently, the selective introduction of $\mathrm{CF}_{2} \mathrm{PO}(\mathrm{OR})_{2}$ groups into aromatic compounds is a topic of considerable interest. Meanwhile, transition metal-catalyzed cross-coupling reactions are now employed for wide repertoire of aromatic carbon-carbon, carbon-heteroatom bond-forming reactions [18]. Fluoro and fluoroalkyl cross-coupling reactions are one of the most powerful methods to construct fluoro aromatic compounds [19-21]. To date, selective introduction of difluoromethylphosphonate groups into aromatics with high generality and functional-group compatibility has been investigated broadly [22-36]. For the construction of $\mathrm{Ar}-\mathrm{CF}_{2} \mathrm{PO}(\mathrm{OR})_{2}$ frameworks, one of the most common and reliable methods is copper-mediated cross-coupling reactions involving $\mathrm{CuCF}_{2} \mathrm{PO}(\mathrm{OR})_{2}$ species $[22,23,25-28,32,33,35]$. Despite such synthetic utility, most of the reported methods require the use of stoichiometric (sometimes, excess) amounts of copper reagents to complete these cross-coupling reactions $[26,28]$. There have been few and limited successful examples in which a small amount of transition metal complexes promoted cross-coupling reactions for introducing difluoromethyl-phosphonate moieties. Due to the demand for $\mathrm{Ar}_{-} \mathrm{CF}_{2} \mathrm{PO}(\mathrm{OR})_{2}$ compounds, a general catalytic approach is required. As a cross-coupling participant, [(trimethylsilyl)difluoromethyl]phosphonate $\left(\mathrm{Me}_{3} \mathrm{Si}_{-}-\mathrm{CF}_{2} \mathrm{PO}(\mathrm{OEt})_{2}: 2\right)$ is stable and readily available 
from $\mathrm{Br}-\mathrm{CF}_{2} \mathrm{PO}(\mathrm{OEt})_{2}$ [37]. Herein, we describe fundamental studies on $\mathrm{Cu}$-mediated cross-coupling of aryl iodides 1 and [(silyl)difluoromethyl]phosphonate $\mathbf{2}$ to deliver $\mathrm{Ar}-\mathrm{CF}_{2} \mathrm{PO}(\mathrm{OEt})_{2} \mathbf{3}$ (Scheme 1).

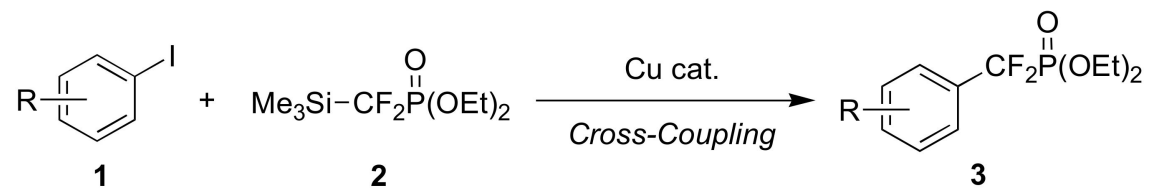

Scheme 1. Cross-coupling of aryl iodides 1 with (silyldifluoromethyl)phosphonate 2.

\section{Results and Discussion}

Initially, we surveyed the suitable reaction conditions for Cu-promoted cross-coupling of aryl iodides $\mathbf{1}$ with (silyldifluoromethyl)phosphonates $\mathbf{2}$. When a mixture of 4 -iodobenzonitrile (1a) and [(trimethylsilyl)difluoromethyl]phosphonates (2) in toluene was heated at $60^{\circ} \mathrm{C}$ for $24 \mathrm{~h}$ in the presence of CuI (1.0 equiv.) and KF (1.2 equiv.), the desired cross-coupling product 3a was not obtained at all (Table 1, Entry 1). Next, we conducted the reaction using a polar aprotic solvent such as DMSO, and as a consequence, aryl(difluoromethyl)phosphonate 3a was obtained in $43 \%$ NMR yield (Entry 2 ). The use of amide solvents such as NMP and DMF was effective for the formation of phosphonate $3 \mathrm{a}$ in $55 \%$ and $76 \%$ yields, respectively (Entries 3 and 4). Furthermore, THF was one of the promising solvents for the Cu-mediated transformation to afford 3a in 74\% NMR yield (Entry 5). Then, we focused our attention on fluoride sources. Instead of potassium fluoride, the use of tetrabutylammonium fluoride (TBAF) in DMF resulted in protodesilylation of 2 to yield $\mathrm{HCF}_{2} \mathrm{PO}(\mathrm{OEt})_{2}$ as a major product (Entry 6). Cesium fluoride was found to be effective to the cross-coupling reaction Entry 7). The combination of $\mathrm{CsF}$ as a fluoride source and THF as a solvent gave the highest product yield of 3a (Entry 8).

Table 1. CuI-promoted cross-coupling of $p$-iodobenzonitrile (1a) with [(trimethylsilyl)difluoromethyl] phosphonate (2): Screening of solvents and fluorides ${ }^{1}$.

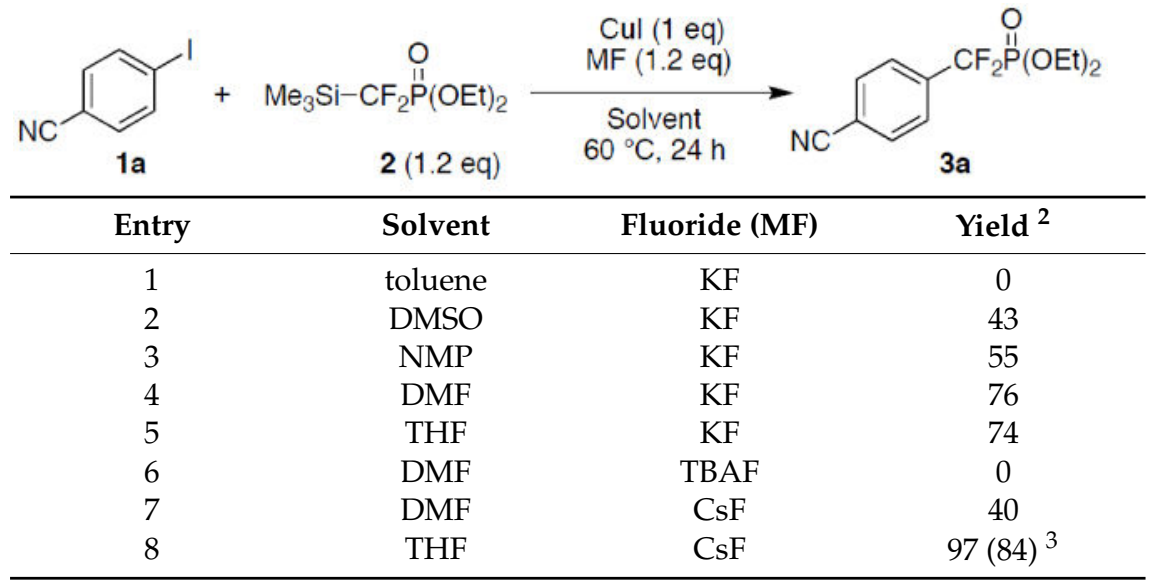

\footnotetext{
${ }^{1}$ Each reaction of 4-iodobenzonitrile $(\mathbf{1 a} 0.50 \mathrm{mmol})$ with $\mathrm{Me}_{3} \mathrm{Si}_{-} \mathrm{CF}_{2} \mathrm{PO}(\mathrm{OEt})_{2}(\mathbf{2} 0.60 \mathrm{mmol})$ was carried out in the presence of CuI $(0.50 \mathrm{mmol})$, and KF (TBAF or CsF) $(0.60 \mathrm{mmol})$ in solvent $(1.0 \mathrm{~mL})$ at $60^{\circ} \mathrm{C}$ for $24 \mathrm{~h}^{2}{ }^{2}$ Each yield was calculated by ${ }^{19} \mathrm{~F}-\mathrm{NMR}$ analysis of the crude product using $\mathrm{CF}_{3} \mathrm{CH}_{2} \mathrm{OH}$ as an internal standard. ${ }^{3}$ The value in parenthesis indicates the isolated yield of $\mathbf{3 a}$.
}

With optimized reaction conditions in hand, other examples of the selective formation of aryl(difluoromethyl)phosphonate 3 were tested (Table 2). Upon treatment with a stoichiometric amount of $\mathrm{CuI}$, a wide repertoire of aryl iodides $\mathbf{1}$ underwent cross-coupling reactions to give the corresponding difluoromethylphosphonates 3 in moderate to good yields. Of significant interest, the present protocol worked well for both electron-deficient and electron-rich iodoarenes (1a-d). Cyano and ester groups in $\mathbf{1 a}$ and $\mathbf{1} \mathbf{b}$ were tolerable under the nucleophilic fluoroalkylating conditions. The cross-coupling of 1-iodonaphthalene (1e) with silyl phosphonate $\mathbf{2}$ proceeded to afford naphthyl difluoromethylphosphonate 3e. Furthermore, heteroarenes $\mathbf{1 f}$ and $\mathbf{1 g}$ underwent the 
difluoromethylenephosphonation to give $\mathbf{3 f}$ and $\mathbf{3 g}$ in 51\% and 70\% isolated yields, respectively. Notably, chloro and bromo functionalities in $\mathbf{3 h}$ and $\mathbf{3 i}$ were compatible with the present transformation. In the each cross-coupling of 1 with 2, the major by-product was $\mathrm{HCF}_{2} \mathrm{PO}(\mathrm{OEt})_{2}$; for instance, the reaction of 2-iodopyridine (1f) with 2 gave $25 \%$ of $\mathrm{HCF}_{2} \mathrm{PO}(\mathrm{OEt})_{2}$ besides the desired $\mathrm{Py}-\mathrm{CF}_{2} \mathrm{P}(\mathrm{O})(\mathrm{OEt})_{2}(3 \mathrm{f})$. With a good level of functional group tolerance, the reactions proceeded smoothly under mild conditions.

Table 2. CuI-mediated cross-coupling of iodoarenes $\mathbf{1}$ with [(trimethylsilyl)difluoromethyl] phosphonate (2) ${ }^{1-3}$.

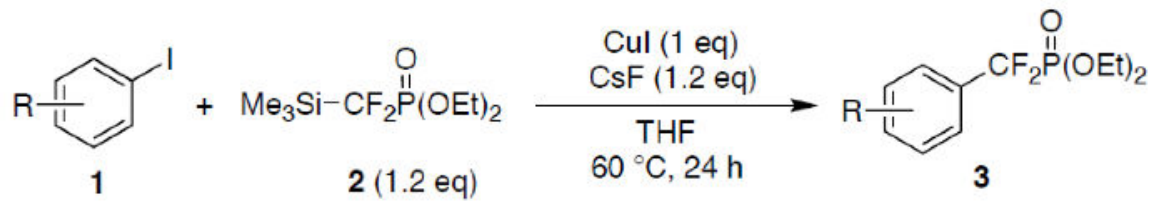<smiles>CCOP(=O)(F)Cc1ccc(C#N)cc1</smiles>

$3 a$

$84 \%$<smiles>CCOP(=O)(Cc1ccc(OC)cc1)OCC</smiles>

$3 d$

$36 \%(51 \%)$<smiles>CCOP(=O)(F)[Te+]c1ccc2ccccc2n1</smiles>

$3 \mathrm{~g}$

$70 \%$

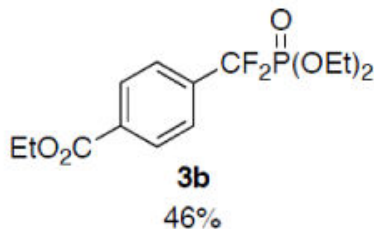<smiles>CCOP(=O)(Cc1ccccc1)Cc1ccccc1</smiles><smiles>CCOP(=O)(F)[C-](C)c1cccc2ccccc12</smiles><smiles>CCOP(=O)([18O]c1ccccn1)c1ccccn1</smiles><smiles>CCOP(=O)(F)[C+]c1ccc(Cl)c(Cl)c1</smiles>

$3 h$<smiles>CCOP(=O)(F)[C-](C)c1ccc(Br)cc1</smiles>

$3 i$

$58 \%$

\footnotetext{
${ }^{1}$ Each reaction of 4-iodobenzonitrile $(1 \mathrm{a} 0.50 \mathrm{mmol})$ with $\mathrm{Me}_{3} \mathrm{Si}_{-}-\mathrm{CF}_{2} \mathrm{PO}(\mathrm{OEt})_{2}(20.60 \mathrm{mmol})$ was carried out in the presence of $\mathrm{CuI}(0.50 \mathrm{mmol})$, and $\mathrm{CsF}(0.60 \mathrm{mmol})$ in solvent $(1.0 \mathrm{~mL})$ at $60^{\circ} \mathrm{C}$ for $24 \mathrm{~h} .{ }^{2}$ Isolated yields of $3 .{ }^{3}$ The value in parenthesis indicates the yield calculated by ${ }^{19} \mathrm{~F}-\mathrm{NMR}$ analysis of the crude product using $\mathrm{CF}_{3} \mathrm{CH}_{2} \mathrm{OH}$ as an internal standard.
}

Copper-mediated cross-coupling of aryl iodides with $\mathrm{BrZnCF}_{2} \mathrm{PO}(\mathrm{OEt})_{2}$ is one of the most reliable methods for the synthesis of $\mathrm{Ar}-\mathrm{CF}_{2} \mathrm{PO}(\mathrm{OEt})_{2}$ species (Scheme 2) [23]. However, there is a technical drawback for the transmetallation methodology using $\mathrm{BrZnCF}_{2} \mathrm{PO}(\mathrm{OEt})_{2}$ and $\mathrm{BrCdCF}_{2} \mathrm{PO}(\mathrm{OEt})_{2}$; in most cases, the use of stoichiometric amounts of copper salts is needed to complete the cross-coupling reactions. Poisson and co-workers reported the cross-coupling reactions of $\mathrm{Me}_{3} \mathrm{Si}-\mathrm{CF}_{2} \mathrm{PO}(\mathrm{OEt})_{2}(2)$ with aryl diazonium salts and iodonium salts upon exposure to a stoichiometric amount of CuSCN [35]. In 2012, Zhang overcame the shortcoming of Cu-mediated cross-coupling for install of $\mathrm{CF}_{2} \mathrm{PO}(\mathrm{OEt})_{2}$ group into aryl rings [26]. As a key strategy, employing the aryl iodides (or aryl bromides) possessing directing substituents such as methoxycarbonyl or triazene groups at the ortho-position in aryl iodides to facilitate the oxidative addition. Anyway, in order to accomplish the reactions promoted by a small amount of copper complexes, there is a limitation concerning the substrates endowed with ortho-directing groups [26,28]. 
Shibuya et al.

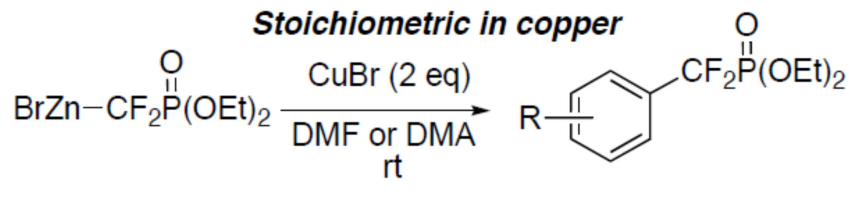

Burton et al.

Stoichiometric in copper

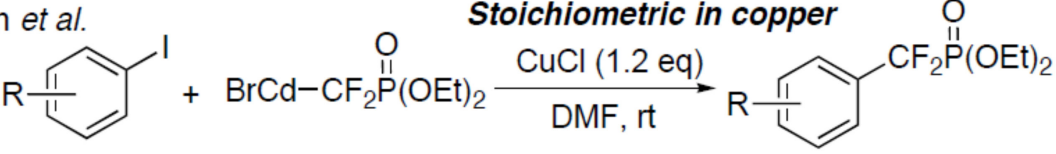

1

Poisson et al.

Stoichiometric in copper

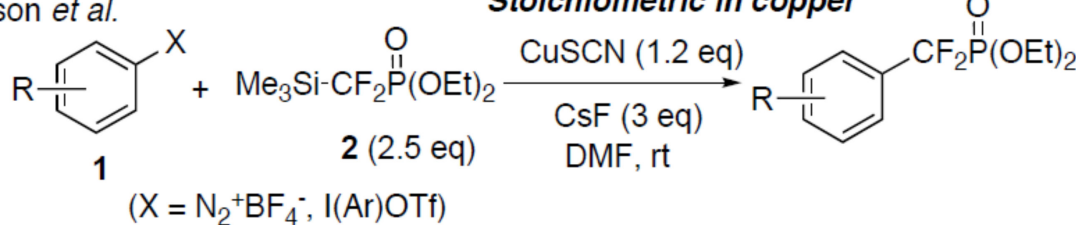

Zhang et al.

\section{Catalytic in copper}

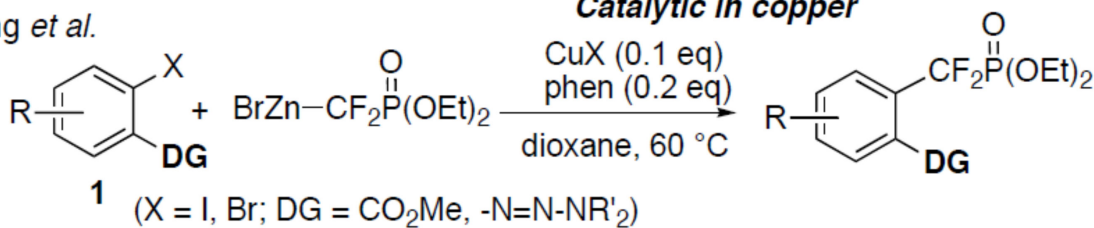

Scheme 2. Cu-mediated/catalyzed cross-coupling for the synthesis of aryl(difluoromethyl) phosphonates.

We examined the reactions of aryl iodides $\mathbf{1}$ with (silyldifluoromethyl)phosphonate $\mathbf{2}$ by the use of a small amount of CuI (Scheme 3).

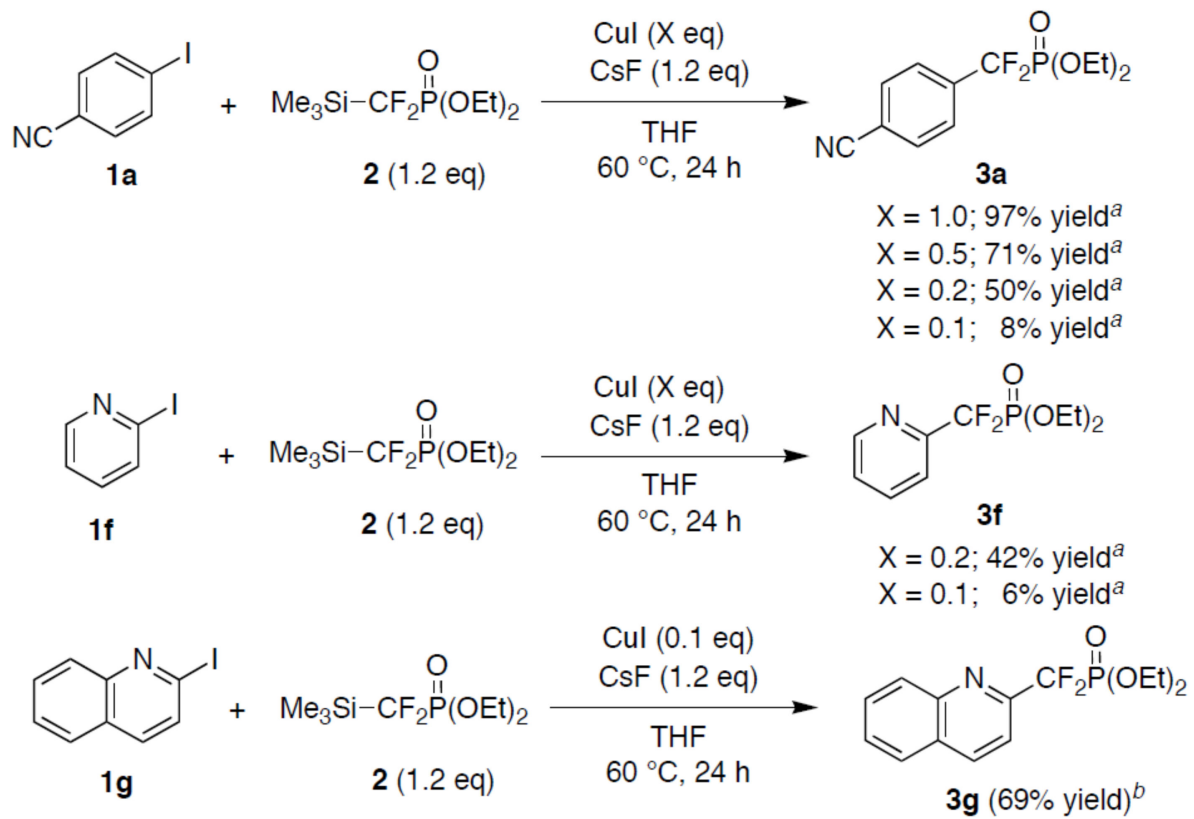

Scheme 3. Cu-catalyzed difluoromethylenephosphonation of aryl iodides. ${ }^{\text {a }}$ Each yield was calculated by ${ }^{19} \mathrm{~F}-\mathrm{NMR}$ analysis of the crude product using $\mathrm{CF}_{3} \mathrm{CH}_{2} \mathrm{OH}$ as an internal standard. ${ }^{b}$ Isolated yield of $3 \mathrm{~g}$.

When a mixture of 1a, phosphonates 2 and $\mathrm{CsF}$ in $\mathrm{THF}$ was heated at $60{ }^{\circ} \mathrm{C}$ for $24 \mathrm{~h}$ in the presence of $\mathrm{CuI}(0.5$ equiv. to 1a) under argon atmosphere, the cross-coupling reaction proceeded to give $3 \mathbf{a}$ in $71 \%$ yield. Upon treatment with further reduced amount of $\mathrm{CuI}$ ( 0.2 equiv. to $\mathbf{1 a}$ and 1f), the cross-coupling products $\mathbf{3 a}$ and $\mathbf{3 f}$ were obtained in $50 \%$ and $42 \%$ NMR yields, respectively. Interestingly, iodoquinoline participated in cross-coupling reaction to afford 
difluoromethylphosphonate $3 \mathrm{~g}$ in $69 \%$ yield at $10 \mathrm{~mol} \%$ catalyst loading. Control of the rate of the generation of $\mathrm{CF}_{2} \mathrm{PO}(\mathrm{OEt})_{2}$ anion by the reaction of $\mathrm{Me}_{3} \mathrm{Si}_{-}-\mathrm{CF}_{2} \mathrm{PO}(\mathrm{OEt})_{2}(2)$ with $\mathrm{CsF}$ would render a reaction catalytic in copper possible. The major role of $\mathrm{CsF}$ is the activation of organosilicon compound 2 to generate $\mathrm{CF}_{2} \mathrm{PO}(\mathrm{OEt})_{2}$ anion. The low solubility of $\mathrm{CsF}$ in THF would contribute to slow generation of $\mathrm{CF}_{2} \mathrm{PO}(\mathrm{OEt})_{2}$ anion and formation of $\mathrm{CuCF}_{2} \mathrm{PO}(\mathrm{OEt})_{2}$ species in the catalytic reactions.

\section{Materials and Methods}

\subsection{General Information}

All reactions were carried out under an argon atmosphere in flame-dried glassware. Syringes used to transfer anhydrous solvents or reagents were purged with argon prior to use. Most chemicals were purchased from commercial suppliers and used without further purification. THF was dried by reflux over Na chips in the presence of benzophenone as indicator. Analytical TLC was performed on aluminum silica gel $60 \mathrm{~F}_{254}$ (Merck, Darmstadt, Germany) sheets, which were visualized by the quenching of UV fluorescence $(254 \mathrm{~nm})$. Column chromatography was conducted on silica gel (Cica, 60-210 mesh, spherical, neutral). NMR spectra were acquired on a JNMECS $400\left(400 \mathrm{MHz}\right.$ for ${ }^{1} \mathrm{H}$ and $376 \mathrm{MHz}$ for ${ }^{19} \mathrm{~F}$, respectively) spectrometer (JEOL, Ltd., Tokyo, Japan). ${ }^{1} \mathrm{H}-\mathrm{NMR}$ spectra were recorded using TMS $\left(\mathrm{Me}_{4} \mathrm{Si}\right)$ as internal standard $(\delta=0) .{ }^{19} \mathrm{~F}-\mathrm{NMR}$ spectra were recorded using hexafluorobenzene $\left(\mathrm{C}_{6} \mathrm{~F}_{6}\right)$ as internal standard $(\delta=0)$. All the ${ }^{1} \mathrm{H}-\mathrm{NMR}$ and ${ }^{19} \mathrm{~F}-\mathrm{NMR}$ spectra of 3 matched those reported previously $[23,25,31,35]$.

\subsection{Cross-Coupling of Aryl Iodides with $\mathrm{Me}_{3} \mathrm{SiCF}_{2} \mathrm{PO}(\mathrm{OEt})_{2}$}

To a mixture of CuI (95.2 mg, $0.50 \mathrm{mmol}), \mathrm{CsF}(91.1 \mathrm{mg}, 0.60 \mathrm{mmol})$, 4-iodobenzonitrile (1a, $114.0 \mathrm{mg}, 0.50 \mathrm{mmol})$, and THF $(1.0 \mathrm{~mL})$ was added [(trimethylsilyl)difluoromethyl]phosphonate (2, $156.2 \mathrm{mg}, 0.60 \mathrm{mmol}$ ) at room temperature. The reaction mixture was stirred at $60{ }^{\circ} \mathrm{C}$ in an atmosphere of nitrogen for $24 \mathrm{~h}$ and quenched with water. The aqueous layer was extracted with ethyl acetate. Then, the combined organic phase was washed with water, dried over anhydrous $\mathrm{Na}_{2} \mathrm{SO}_{4}$. The crude product was purified by column chromatography on silica gel (hexane/EtOAc $=2 / 1$ ) to give 3a (121.4 $\mathrm{mg}, 0.42 \mathrm{mmol}, 84 \%$ ) as a pale-yellow oil.

Diethyl (4-cyanophenyl)difluoromethylphosphonate (3a). ${ }^{1} \mathrm{H}-\mathrm{NMR}\left(\mathrm{CDCl}_{3}\right)$ : 7.82-7.71 (m, $\left.4 \mathrm{H}\right)$, 4.35-4.18 (m, 4H), $1.34(\mathrm{t}, J=7.2 \mathrm{~Hz}, 6 \mathrm{H}) ;{ }^{19} \mathrm{~F}-\mathrm{NMR}\left(\mathrm{CDCl}_{3}\right): 51.7(\mathrm{~d}, J=112.8 \mathrm{~Hz}, 2 \mathrm{~F})$.

Ethyl 4-[(diethoxyphosphoryl)difluoromethyl]benzoate (3b). Following a general procedure, CuI (95.2 mg, $0.50 \mathrm{mmol}), \mathrm{CsF}(91.1 \mathrm{mg}, 0.60 \mathrm{mmol})$, ethyl 4-iodobenzoate (1b, $138.0 \mathrm{mg}, 0.50 \mathrm{mmol})$, [(trimethylsilyl)difluoromethyl]phosphonate $(2,156.2 \mathrm{mg}, 0.60 \mathrm{mmol})$ were used in THF $(1.0 \mathrm{~mL})$ at $60{ }^{\circ} \mathrm{C}$ for $24 \mathrm{~h}$. The crude product was purified by column chromatography on silica gel (hexane $/ \mathrm{EtOAc}=2 / 1)$ to give product $2 \mathbf{b}\left(77.4 \mathrm{mg}, 46 \%\right.$ yield) as a pale yellow oil. ${ }^{1} \mathrm{H}-\mathrm{NMR}\left(\mathrm{CDCl}_{3}\right)$ : $8.13(2 \mathrm{H}, \mathrm{d}, J=8.4), 7.70(2 \mathrm{H}, \mathrm{d}, J=8.4), 4.41(2 \mathrm{H}, \mathrm{q}, J=7.2), 4.26-4.12(4 \mathrm{H}, \mathrm{m}), 1.41(3 \mathrm{H}, \mathrm{t}, J=7.2), 1.32$ $(6 \mathrm{H}, \mathrm{t}, J=7.2) ;{ }^{19} \mathrm{~F}-\mathrm{NMR}\left(\mathrm{CDCl}_{3}\right): 52.4(\mathrm{~d}, J=112.8 \mathrm{~Hz}, 2 \mathrm{~F})$.

Diethyl difluoro(phenyl)methylphosphonate (3c). Following a general procedure, CuI (95.2 mg, $0.50 \mathrm{mmol}), \mathrm{CsF}(91.1 \mathrm{mg}, 0.60 \mathrm{mmol}$ ), iodobenzene (1c, $102.0 \mathrm{mg}, 0.50 \mathrm{mmol}$ ), [(trimethylsilyl)-difluoromethyl]phosphonate $(2,156.2 \mathrm{mg}, 0.60 \mathrm{mmol})$ were used in THF $(1.0 \mathrm{~mL})$ at $60{ }^{\circ} \mathrm{C}$ for $24 \mathrm{~h}$. The crude product was purified by column chromatography on silica gel (hexane $/ \mathrm{EtOAc}=3 / 1)$ to give product $2 \mathrm{c}\left(76.1 \mathrm{mg}, 57 \%\right.$ yield) as a pale-yellow oil. ${ }^{1} \mathrm{H}-\mathrm{NMR}\left(\mathrm{CDCl}_{3}\right)$ : $7.63(2 \mathrm{H}, \mathrm{d}, J=8.0), 7.50-7.45(3 \mathrm{H}, \mathrm{m}), 4.26-4.13(4 \mathrm{H}, \mathrm{m}), 1.31(6 \mathrm{H}, \mathrm{t}, J=7.0) ;{ }^{19} \mathrm{~F}-\mathrm{NMR}\left(\mathrm{CDCl}_{3}\right): 53.2(\mathrm{~d}$, $J=116.6 \mathrm{~Hz}, 2 \mathrm{~F})$.

Diethyl (4-methoxyphenyl)difluoromethylphosphonate (3d) Following a general procedure, CuI (95.2 mg, $0.50 \mathrm{mmol}), \mathrm{CsF}$ (91.1 mg, $0.60 \mathrm{mmol})$, 1-ethoxy-4-iodobenzene (1d, $117.0 \mathrm{mg}, 0.50 \mathrm{mmol}$ ), [(trimethylsilyl)difluoromethyl]phosphonate $(2,157.5 \mathrm{mg}, 0.61 \mathrm{mmol})$ were used in THF $(1.0 \mathrm{~mL})$ 
at $60{ }^{\circ} \mathrm{C}$ for $24 \mathrm{~h}$. The crude product was purified by column chromatography on silica gel (hexane $/ \mathrm{EtOAc}=3 / 1)$ to give product $2 \mathrm{~d}\left(51.1 \mathrm{mg}, 36 \%\right.$ yield) as a colorless oil. ${ }^{1} \mathrm{H}-\mathrm{NMR}\left(\mathrm{CDCl}_{3}\right)$ : $7.95(2 \mathrm{H}, \mathrm{d}, J=7.6), 7.54(2 \mathrm{H}, \mathrm{d}, J=7.6), 4.23-4.10(4 \mathrm{H}, \mathrm{m}), 3.83(3 \mathrm{H}, \mathrm{s}), 1.30(6 \mathrm{H}, \mathrm{t}, J=6.8) ;{ }^{19} \mathrm{~F}-\mathrm{NMR}$ $\left(\mathrm{CDCl}_{3}\right): 54.6(\mathrm{~d}, J=115.8 \mathrm{~Hz}, 2 \mathrm{~F})$.

Diethyl difluoro(naphthalen-1-yl)methylphosphonate (3e). Following a general procedure, CuI (95.2 mg, $0.50 \mathrm{mmol}), \mathrm{CsF}(91.1 \mathrm{mg}, 0.60 \mathrm{mmol}), 1$-iodonaphthalene (1e, $127.0 \mathrm{mg}, 0.50 \mathrm{mmol})$, [(trimethylsilyl)difluoromethyl]phosphonate $(2,156.2 \mathrm{mg}, 0.60 \mathrm{mmol})$ were used in THF (1.0 mL) at $60{ }^{\circ} \mathrm{C}$ for $24 \mathrm{~h}$. The crude product was purified by column chromatography on silica gel (hexane $/ \mathrm{EtOAc}=3 / 1)$ to give product $2 \mathrm{e}\left(77.1 \mathrm{mg}, 49 \%\right.$ yield) as a colorless oil. ${ }^{1} \mathrm{H}-\mathrm{NMR}\left(\mathrm{CDCl}_{3}\right)$ : $8.44(1 \mathrm{H}, \mathrm{d}, J=8.4), 7.97(1 \mathrm{H}, \mathrm{d}, J=8.4), 7.88(1 \mathrm{H}, \mathrm{d}, J=8.4), 7.81(1 \mathrm{H}, \mathrm{d}, J=7.2), 7.60-7.48(3 \mathrm{H}, \mathrm{m})$, 4.24-4.00 (4H, m), $1.27(6 \mathrm{H}, \mathrm{t}, J=7.2) ;{ }^{19} \mathrm{~F}-\mathrm{NMR}\left(\mathrm{CDCl}_{3}\right): 53.2(\mathrm{~d}, J=112.8 \mathrm{~Hz}, 2 \mathrm{~F})$.

Diethyl difluoro(pyridin-2-yl)methylphosphonate (3f). Following a general procedure, CuI (95.2 mg, $0.50 \mathrm{mmol}), \mathrm{CsF}$ (91.1 mg, $0.60 \mathrm{mmol})$, 2-iodopyridine (1f, $102.5 \mathrm{mg}, 0.50 \mathrm{mmol}$ ), [(trimethylsilyl)difluoromethyl]phosphonate $(2,157.6 \mathrm{mg}, 0.61 \mathrm{mmol})$ were used in THF (1.0 mL) at $60{ }^{\circ} \mathrm{C}$ for $24 \mathrm{~h}$. The crude product was purified by column chromatography on silica gel (hexane $/$ EtOAc $=2 / 1)$ to give product $2 \mathrm{e}\left(67.0 \mathrm{mg}, 51 \%\right.$ yield) as a pale yellow oil. ${ }^{1} \mathrm{H}-\mathrm{NMR}\left(\mathrm{CDCl}_{3}\right)$ : $8.72(1 \mathrm{H}, \mathrm{d}, J=4.4), 7.85(1 \mathrm{H}, \mathrm{t}, J=8.0), 7.71(1 \mathrm{H}, \mathrm{d}, J=8.0), 7.44-7.41(1 \mathrm{H}, \mathrm{m}), 4.24-4.37(4 \mathrm{H}, \mathrm{m}), 1.36$ $(6 \mathrm{H}, \mathrm{t}, J=7.0) ;{ }^{19} \mathrm{~F}-\mathrm{NMR}\left(\mathrm{CDCl}_{3}\right): 51.1(\mathrm{~d}, J=109.8 \mathrm{~Hz}, 2 \mathrm{~F})$.

Diethyl difluoro(quinolin-2-yl)methylphosphonate (3g). To a mixture of CuI (9.5 mg, $0.05 \mathrm{mmol}), \mathrm{CsF}(91.1 \mathrm{mg}, 0.60 \mathrm{mmol}), 2$-iodoquinoline (1g, $127.5 \mathrm{mg}, 0.50 \mathrm{mmol})$, [(trimethylsilyl)difluoromethyl]-phosphonate $(2,151.0 \mathrm{mg}, 0.58 \mathrm{mmol})$, and THF $(1.0 \mathrm{~mL})$ was added [(trimethylsilyl)-difluoromethyl]phosphonate $(2,156.2 \mathrm{mg}, 0.60 \mathrm{mmol})$ at room temperature. The reaction mixture was stirred at $60{ }^{\circ} \mathrm{C}$ in an atmosphere of nitrogen for $24 \mathrm{~h}$ and quenched with water. The aqueous layer was extracted with ethyl acetate. Then, the combined organic phase was washed with water, dried over anhydrous $\mathrm{Na}_{2} \mathrm{SO}_{4}$. The crude product was purified by column chromatography on silica gel (hexane/EtOAc $=2 / 1)$ to give $3 \mathrm{~g}(110.0 \mathrm{mg}, 69 \%$ yield) as a pale yellow oil. ${ }^{1} \mathrm{H}-\mathrm{NMR}\left(\mathrm{CDCl}_{3}\right)$ ): $8.32(1 \mathrm{H}, \mathrm{d}, J=8.4), 8.19(1 \mathrm{H}, \mathrm{d}, J=8.4), 7.89(1 \mathrm{H}, \mathrm{d}, J=8.0), 7.81-7.77(1 \mathrm{H}, \mathrm{m}), 7.64$ $(1 \mathrm{H}, \mathrm{t}, J=8.0), 4.39-4.32(4 \mathrm{H}, \mathrm{m}), 1.38(6 \mathrm{H}, \mathrm{t}, J=7.2) ;{ }^{19} \mathrm{~F}-\mathrm{NMR}\left(\mathrm{CDCl}_{3}\right): 51.1(\mathrm{~d}, J=103.8 \mathrm{~Hz}, 2 \mathrm{~F})$.

Diethyl (3,4-dichlorophenyl)difluoromethylphosphonate (3h). Following a general procedure, CuI (91.4 mg, $0.48 \mathrm{mmol}), \mathrm{CsF}$ (89.3 mg, $0.59 \mathrm{mmol}), 3,4$-dichloro-1-iodobenzene (1h, $131.7 \mathrm{mg}, 0.48 \mathrm{mmol}$ ), [(trimethylsilyl)difluoromethyl]phosphonate $(2,153.1 \mathrm{mg}, 0.58 \mathrm{mmol})$ were used in THF $(1.0 \mathrm{~mL})$ at $60{ }^{\circ} \mathrm{C}$ for $24 \mathrm{~h}$. The crude product was purified by column chromatography on silica gel (hexane/EtOAc $=3 / 1)$ to give product $3 \mathrm{~h}\left(71.2 \mathrm{mg}, 44 \%\right.$ yield) as a pale yellow oil. ${ }^{1} \mathrm{H}-\mathrm{NMR}\left(\mathrm{CDCl}_{3}\right)$ : $7.70(1 \mathrm{H}, \mathrm{s}), 7.55(1 \mathrm{H}, \mathrm{d}, J=8.3), 7.47(1 \mathrm{H}, \mathrm{d}, J=8.3), 4.33-4.14(4 \mathrm{H}, \mathrm{m}), 1.35(6 \mathrm{H}, \mathrm{t}, J=7.0) ;{ }^{19} \mathrm{~F}-\mathrm{NMR}$ $\left(\mathrm{CDCl}_{3}\right): 52.8(2 \mathrm{~F}, \mathrm{~d}, J=113.4 \mathrm{~Hz})$.

Diethyl (4-bromophenyl)difluoromethylphosphonate (3i). Following a general procedure, CuI (95.2 mg, $0.50 \mathrm{mmol}), \mathrm{CsF}$ (91.1 mg, $0.60 \mathrm{mmol})$, 4-bromo-1-iodobenzene (1i, $142.0 \mathrm{mg}, 0.50 \mathrm{mmol}$ ), [(trimethylsilyl)difluoromethyl]phosphonate $(2,156.2 \mathrm{mg}, 0.60 \mathrm{mmol})$ were used in THF (1.0 mL) at $60{ }^{\circ} \mathrm{C}$ for $24 \mathrm{~h}$. The crude product was purified by column chromatography on silica gel (hexane/EtOAc $=3 / 1)$ to give product $3 \mathbf{i}\left(100.0 \mathrm{mg}, 58 \%\right.$ yield) as a pale yellow oil. ${ }^{1} \mathrm{H}-\mathrm{NMR}\left(\mathrm{CDCl}_{3}\right)$ : $7.60(2 \mathrm{H}, \mathrm{d}, J=8.4), 7.49(2 \mathrm{H}, \mathrm{d}, J=8.4), 4.10-4.30(4 \mathrm{H}, \mathrm{m}), 1.33(6 \mathrm{H}, \mathrm{t}, J=7.1) ;{ }^{19} \mathrm{~F}-\mathrm{NMR}\left(\mathrm{CDCl}_{3}\right): 52.8$ $(2 \mathrm{~F}, \mathrm{~d}, J=113.4 \mathrm{~Hz})$.

\section{Conclusions}

In summary, we have developed a convenient route to aryl(difluoromethyl)phosphonates from aryl iodides. Using a simple combination of the coupling partners (iodoarenes and $\left.\mathrm{Me}_{3} \mathrm{Si}-\mathrm{CF}_{2} \mathrm{PO}(\mathrm{OEt})_{2}\right)$, the cross-coupling proceeded smoothly under mild reaction conditions. The present transformations employing $\mathrm{CuI}$ are synthetically useful. In some cases, a small amount 
of CuI promoted the cross-coupling reactions to afford aryl(difluoromethyl)phosphonates. From the practical viewpoint, this study will enable the development of valuable organofluorine compounds with potential biological utility.

Author Contributions: H.A. directed the project and designed the experiments; K.K., R.I. and M.K. performed the experiments and analyzed the data; K.K. and H.A. wrote the paper.

Funding: The financial support of JSPS KAKENHI Grant No. JP 16H04143 (Grant-in-Aid for Scientific Research (B)), JP18H04235 in Middle Molecular Strategy, 18H04381 in Precisely Designed Catalysts with Customized Scaffolding, and Japan Science and Technology Agency (JST) (ACT-C: Creation of Advanced Catalytic Transformation for the Sustainable Manufacturing at Low Energy, Low Environmental Load) is acknowledged.

Acknowledgments: We would like to thank Masahiko Hayashi (Kobe University) and Hiroshi Sano (Gunma University) for their useful suggestions.

Conflicts of Interest: The authors declare no conflicts of interest.

\section{References}

1. Banks, R.E.; Smart, B.E.; Tatlow, J.C. Organofluorine Chemistry: Principles and Commercial Applications; Plenum Press: New York, NY, USA, 1994.

2. Hiyama, T.; Kanie, K.; Kusumoto, T.; Morizawa, Y.; Shimizu, M. Organofluorine Compounds: Chemistry and Application; Springer-Verlag: Berlin, Germany, 2000.

3. Kirsch, P. Modern Fluoroorganic Chemistry; Wiley-VCH: Weinheim, Germany, 2004.

4. Chambers, R.D. Fluorine in Organic Chemistry; Blackwell: Oxford, UK, 2004.

5. Uneyama, K. Organofluorine Chemistry; Blackwell: Oxford, UK, 2006.

6. Bégué, J.-P.; Bonnet-Delpon, D. Bioorganic and Medicinal Chemistry of Fluorine; John Wiley \& Sons, Inc.: Hoboken, NJ, USA, 2008.

7. Ojima, I. Fluorine in Medicinal Chemistry and Chemical Biology; Wiley-Blackwell: Chichester, UK, 2009.

8. Gouverneur, V.; Müller, K. Fluorine in Pharmaceutical and Medicinal Chemistry: From Biophysical Aspects to Clinical Applications; World Scientific Publishing Company: London, UK, 2012.

9. Wang, J.; Sánchez-Roselló, M.; Aceña, J.L.; del Pozo, C.; Sorochinsky, A.E.; Fustero, S.; Soloshonok, V.A.; Liu, H. Fluorine-containing drugs introduced to the market in the last decade (2001-2011). Chem. Rev. 2014, 114, 2432-2506. [CrossRef] [PubMed]

10. Blackburn, C.M.; England, D.A.; Kolkmann, F. Monofluoro- and difluoro-methylenebisphosphonic acids: Isopolar analogues of pyrophosphoric acid. J. Chem. Soc. Chem. Commun. 1981, 930-932. [CrossRef]

11. Blackburn, G.M.; Kent, D.E.; Kolkmann, F. The synthesis and metal binding characteristics of novel, isopolar phosphonate analogues of nucleotides. J. Chem. Soc. Perkin Trans. 1 1984, 1119-1125. [CrossRef]

12. Romanenko, V.D.; Kukhar, V.P. Fluorinated phosphonates: Synthesis and biomedical application. Chem. Rev. 2006, 106, 3868-93. [CrossRef] [PubMed]

13. Burke, T.R.; Lee, J.R.K. Phosphotyrosyl mimetics in the development of signal transduction inhibitors. Acc. Chem. Res. 2003, 36, 426-433. [CrossRef] [PubMed]

14. Zhang, Z.-Y. Chemical and mechanistic approaches to the study of protein tyrosine phosphatases. Acc. Chem. Res. 2003, 36, 385-392. [CrossRef] [PubMed]

15. Hikishima, S.; Hashimoto, M.; Magnowska, L.; Bzowska, A.; Yokomatsu, T. Synthesis and biological evaluation of 9-deazaguanine derivatives connected by a Linker to difluoromethylene phosphonic acid as multi-substrate analogue Inhibitors of PNP 2007. Bioorg. Med. Chem. Lett. 2010, 20, 2275-2284. [CrossRef] [PubMed]

16. Mandal, P.K.; Liao, W.S.-L.; McMurray, J.S. Synthesis of phosphatase-stable, cell-permeable peptidomimetic prodrugs that target the SH2 domain of Stat3. Org. Lett. 2009, 11, 3394-3397. [CrossRef]

17. Mitra, S.; Barrios, A.M. Identifying selective protein tyrosine phosphatase substrates and inhibitors from a fluorogenic, combinatorial peptide library. ChemBioChem 2008, 9, 1216-1219. [CrossRef]

18. De Meijere, A.; Diederich, F. Metal-Catalyzed Cross-Coupling Reactions; Wiley-VCH: Weinheim, Germany 2004.

19. Braun, T.; Hughes, R.P. Organometallic Fluorine Chemistry (Topics in Organometallic Chemistry 52); Springer International Publishing: Basel, Switzerland, 2015.

20. Jin, Z; Hammond, G.B.; Xu, B. Transition-metal-mediated fluorination, difluoromethylation, and trifluoromethylation. Aldrichimica Acta 2012, 45, 67-83. 
21. Liang, T.; Neumann, C.N.; Ritter, T. Introduction of fluorine and fluorine-containing functional groups. Angew. Chem. Int. Ed. 2013, 52, 8214-8264. [CrossRef] [PubMed]

22. Qiu, W.; Burton, D.J. A facile and general preparation of $\alpha, \alpha$-difluoro benzylic phosphonates by the $\mathrm{CuCl}$ promoted coupling reaction of the (diethyl phosphonyl)difluoromethylcadmium reagent with aryl iodides. Tetrahedron Lett. 1996, 37, 2745-2748. [CrossRef]

23. Yokomatsu, T.; Murano, T.; Suemune, K.; Shibuya, S. Facile Synthesis of aryl(difluoromethyl)phosphonates through $\mathrm{CuBr}$-mediated cross coupling reactions of [(diethoxyphosphinyl)difluoromethyl]zinc bromide with aryl iodides. Tetrahedron 1997, 53, 815-822. [CrossRef]

24. Murakami, S.; Ishii, H.; Tajima, T.; Fuchigami, T. Photochemical substitution of olefins and aromatic compounds with difluoromethyl radicals bearing ester and phosphonate groups. Tetrahedron 2006, 62, 3761-3769. [CrossRef]

25. Qiu, W.; Burton, D.J. Cuprous chloride promoted coupling reaction of diethoxyphosphinyl-difluoromethylcadmium reagent with aryl iodides: A practical and convenient preparation of $\alpha, \alpha$-difluoro benzylic phosphonates. J. Fluorine Chem. 2013, 155, 45-51. [CrossRef]

26. Feng, Z.; Chen, F.; Zhang, X. Copper catalyzed cross-coupling of iodobenzoates with bromozinc-difluorophosphonate. Org. Lett. 2012, 14, 1938-1941. [CrossRef]

27. Jiang, X.; Chu, L.; Qing, F.-L. Copper-mediated oxidative difluoromethylenation of aryl boronic acids with $\alpha$-silyldifluoromethylphosphonates: A new method for aryldifluorophosphonates. New. J. Chem. 2013, 37, 1736-1741. [CrossRef]

28. Feng, Z.; Xiao, Y.-L.; Zhang, X. Copper-catalyzed cross-coupling of bromozinc-difluoromethylphosphonate with iodo/bromo-aryl triazenes. Org. Chem. Front. 2014, 1, 113-116. [CrossRef]

29. Murakami, S.; Kim, S.; Ishii, H.; Fuchigami, T. Aromatic substitution with photochemically generated difluoromethyl radicals bearing electron-withdrawing group. Synlett. 2014, 5, 815-818. [CrossRef]

30. Wang, L.; Wei, X.-J.; Lei, W.-L.; Chen, H.; Wub, L.-Z.; Liu, Q. Direct C-H difluoromethylenephosphonation of arenes and heteroarenes with bromodifluoromethyl phosphonate via visible-light photocatalysis. Chem. Commun. 2014, 50, 15916-15919. [CrossRef]

31. Feng, Z.; Min, Q.-Q.; Xiao, Y.-L.; Zhang, B.; Zhang, X. Palladium-catalyzed difluoroalkylation of aryl boronic acids: A new method for the synthesis of aryldifluoromethylated phosphonates and carboxylic acid derivatives. Angew. Chem. Int. Ed. 2014, 53, 1669-1673. [CrossRef] [PubMed]

32. Bayle, A.; Cocaud, C.; Nicolas, C.; Martin, O.R.; Poisson, T.; Pannecoucke, X. Copper-mediated synthesis of aryldifluoromethylphosphonates: A Sandmeyer approach. Eur. J. Org. Chem. 2015, 3787-3792. [CrossRef]

33. Ivanova, M.V.; Bayle, A.; Besset, T.; Poisson, T.; Pannecoucke, X. Copper-mediated formation of aryl, heteroaryl, vinyl and alkynyl difluoromethylphosphonates: A general approach to fluorinated phosphate mimics. Angew. Chem. Int. Ed. 2015, 54, 13406-13410. [CrossRef] [PubMed]

34. Li, J.; Wan, W.; Ma, G.; Chen, Y.; Hu, Q.; Kang, K.; Jiang, H.; Hao, J. Silver-mediated C-H difluoromethylation of arenes. Eur. J. Org. Chem. 2016, 4916-4921. [CrossRef]

35. Ivanova, M.V.; Bayle, A.; Besset, T.; Pannecoucke, X.; Poisson, T. Copper-mediated introduction of the $\mathrm{CF}_{2} \mathrm{PO}(\mathrm{OEt})_{2}$ motif: Scope and limitations. Chem. Eur. J. 2017, 23, 17318-17338. [CrossRef] [PubMed]

36. Ivanova, M.V.; Besset, T.; Pannecoucke, X.; Poisson, T. Palladium-catalyzed synthesis of aryl and heteroaryl difluoromethylated phosphonates. Synthesis 2018, 50, 778-784. [CrossRef]

37. Reily, M.D.; Robosky, L.C.; Manning, M.L.; Butler, A.; Baker, J.D.; Winters, R.T. DFTMP, an NMR reagent for assessing the near-neutral $\mathrm{pH}$ of biological samples. J. Am. Chem. Soc. 2006, 128, 12360-12361. [CrossRef]

Sample Availability: Samples of the compounds 3 are available from the authors. 